\title{
THE MAQASID OF ZAKAH AND AWQAF AND THEIR ROLES IN INCLUSIVE FINANCE
}

\author{
Tawfique Al-Mubarak*
}

\begin{abstract}
Financial inclusion refers to the providing of finance to the nonfinanceable segments of the population, who are traditionally denied financial services like banking and insurance facilities due to the absence of collaterals to substantiate their 'bankability'. They are thus considered as 'un-bankable' by formal financial institutions. This 'un-bankable' segment of society is estimated to cover more than 2 billion adults - that is around one third of the world population, and over half of the world's working adults - hindering them from growth, productivity, employment, and stability, compromising the peace and prosperity of society at large. Therefore, the primary aim of inclusive finance is to provide the 'un-bankable' with access to finance, to strengthen domestic resource mobilization and contribute to economic and social development. In recent years, only conventional and Islamic microfinance institutions (ISMFIs) have considered 'inclusive finance' - which includes various delivery channels, like credit unions, banks, insurance and also mobile operators. However, the Islamic institutions of zakah (compulsory alms) and awqaf (perpetual charities) were also ordained with the objectives (maqasid) of eradicating poverty, circulation of wealth, creating a stable and sustainable economy, and enhancing micro, small and large scale infrastructure for social and economic development. This paper attempts to identify the maqasid of these two traditional institutions of the Islamic economy and their potential roles in inclusive finance.
\end{abstract}

Keywords: Zakah and awqaf institutions, poverty alleviation, inclusive finance, sustainable economy, maqasid of zakah and awqaf.

\section{Introduction}

The problem of poverty is the greatest threat to development in many societies. There is still a large segment of people who struggle with poverty on a daily basis despite the presence of numerous microfinance institutions (MFIs). More than 2 billion adults around the globe, that is over half the world's working adults, have yet to be covered by any financial service, due to their absence of proper collateral. ${ }^{1}$ As such, they have been deprived of any financial assistance from formal financial institutions, like banks or insurances. This, along with poverty, has hindered many societies from development and progress. In the recent years, 
themes like 'inclusive finance' have been adopted by development agencies and the microfinance sector to provide financial facilities to more than 2 billion adults of the 'un-bankable' segment, aiming to contribute to a more sustainable social and economic development agenda.

Contemporary Islamic economists have observed that the main contributors to poverty include, among other factors, the absence of justice, equality, fair treatment, as well as barriers to fulfilling basic needs. ${ }^{2}$ Therefore, Islamic finance ought to share the responsibility of eradicating poverty while ensuring justice, equality, fairness, providing basic needs and generating wealth creation among its major principles. The institutions of zakah and awqaf, being among the most effective economic institutions contributing to society's growth and development, are primarily aimed to address the above mentioned problems. However, these remain untapped in most Muslim majority nations. Zakah and awqaf are potential instruments not only for poverty alleviation, but also for creating a sustainable economic environment, answering the problems of food security, sanitation and healthcare services, safe drinking water, employment, and other contemporary challenges which are often addressed within the spheres of 'financial inclusion.'

This paper attempts to identify the inherent objectives (maqasid) of the two institutions, so as to understand the real potentials of these institutions and fulfil those objectives in implementing projects based on zakah and awqaf, towards offering more resilient economic development programs for an inclusive finance agenda.

\section{Zakah and Awqaf, and their Objectives (maqasid)}

\subsection{Zakah}

Literally, the Arabic word 'zakah' means 'growth,' or 'increase'. It also implies 'purification,' 'righteousness,' or 'justification' as it has been used to denote these terms in the Qur'an. ${ }^{4}$ However, in Shari'ah terminology, zakah is "the determined share of wealth prescribed by God to be distributed among deserving categories". ${ }^{5}$ Generally, it is understood as the monetary servitude (ibadah) prescribed by Allah for a Muslim who possesses wealth greater than a prescribed amount (known as nisab), for a complete lunar year. Nisab is the minimum criterion for the 'zakatability' of an item. Anyone who owns less than the nisab is exempted from paying zakah. Based on the Prophetic narrations, the nisab for different items are: 200 dirhams (equivalent to 595 grams) of silver, or 20 dinar (equivalent to 85 grams - of 24 karat quality) of gold, for gold, silver and items which fall under these categories, like cash, shares, or bonds. The nisab for animals and agricultural products vary according to the amount or quantity and quality of the products. ${ }^{6}$ 
Zakah is no doubt one of the most significant institutions of Islam. In early Islamic history zakah proved to be an extremely effective tool for poverty alleviation and inclusive finance. During the rule of Umar ibn al-Khattab between

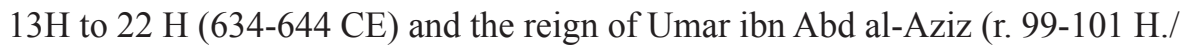
$717-720 \mathrm{CE}$ ), the distribution of zakah was so successful that at one stage no one was qualified to receive zakah, due to the people's improved financial conditions. Umar ibn Abd al-Aziz then wrote to the governor of Egypt to use the zakah money in the construction of bridges and rest houses for travellers, in freeing slaves and in helping young men and women to get married. ${ }^{7}$

Despite tremendous success of poverty alleviation through zakah disbursement in early Islamic history, its immense potentials still remain untapped in the contemporary Muslim world. The current performance of zakah management in the Muslim world is quite poor, with a few exceptions. In many Muslim majority countries, there are no official authority responsible for the management of zakah. ${ }^{8}$ An Islamic Development Bank (IDB) report estimates that the current annual zakah collection is only around USD10 billion per annum. In reality, zakah could potentially generate at least USD 200 billion, implying that only $5 \%$ of total potential zakah is actually being collected throughout the Muslim world. This is only $0.15 \%$ of the OIC member countries' GDP, given the fact that the GDP of the OIC member countries is USD 6 trillion. ${ }^{9}$ These figures indicate that there is a need for a massive reform and revitalisation of the institution of zakah, which is undoubtedly an important tool for the development of inclusive finance and poverty eradication.

\subsection{Awqaf}

Awqaf (plural of waqf) are the non-obligatory philanthropic institutions of Islam and uphold very similar objectives to the institution of zakah. Literally, waqf means 'to uphold,' 'to pause,' 'to secure or confine' (habs), or 'to stop from moving forward. ' ${ }^{10}$ In juridical terms, waqf refers to a property or asset (including cash) which is donated to the cause of Allah (referring to general welfare) and thus is prevented from being owned or sold; rather its extracted usufruct is utilised for the welfare of the community, and righteous or philanthropic activities. The waqif (one who donates an asset as waqf) may stipulate conditions for his waqf, as long as the conditions do not violate the limits of Shari'ah.

Although the term waqf does not appear even for a single instance in the Qur'an, its core idea and principle have been in practice since the time of the Prophet (pbuh) and the companions. When verse 92 of Surah Aal-i-'Imran (3:92) was revealed, urging the believers to spend what they love for the cause of Allah, the companions donated their most beloved properties for righteous and philanthropic activities, marking the initiation of waqf in Islamic history. ${ }^{11}$ Ibn 
Kathir (d. 1373), in his Tafsir Ibn Kathir, specifically mentioned the companion Abu Talha, who had a 'water well' (known as bayruha) facing the Prophet's mosque, from which people would often drink and make ablution. Upon hearing this verse from the Prophet (pbuh), he endowed it as waqf. Similarly, Umar ibn al-Khattab, who later became the second Caliph, went to the Prophet (pbuh) expressing his interest in donating a piece of land in Khaybar, the best of what he possessed. The Prophet (pbuh) suggested he render it as waqf. These imply that one of the core maqasid and teachings of waqf is to curb one's personal greed by sacrificing the best of what one possesses, in exchange for the satisfaction of Allah. Great companions like Abu Bakr, Umar, Uthman, Ali, Zubair, Sa'ad ibn Abi Waqqas, 'Amr ibn al-'As - may Allah be pleased with them all - among many others donated their properties as waqf. This implies that the practice of waqf was prevalent among the companions, and hence its status in Islamic law is undisputed. ${ }^{12}$

Awqaf institutions may comprise several types and can be aimed at different beneficiaries. They can be either religious or philanthropic. Religious awqaf include mosques, shrines, graveyards, Islamic educational institutions like madrasahs, etc. Philanthropic awqaf include the waqf of a property or asset for a specific philanthropic purpose, like medical aid, general education, inns, etc. Similarly, the beneficiaries of a waqf may be family members (waqf ahli/dhurri), or the general public. ${ }^{13}$

One of the fundamental characteristics of waqf is that it is a perpetual charity, unlike zakah which is an occasional or recurring charity. This is also reflected in another Prophetic hadith, when he (pbuh) mentioned that only three types of activities bring forth benefit for a person after his death: a) a continuous charity, b) knowledge which benefits others, and c) a child who prays for his deceased parents. ${ }^{14}$ Perpetuity of waqf renders it the characteristic of a sustainable development instrument, which is instrumental for poverty alleviation as well as inclusive finance.

\subsection{The Maqasid of Zakah and Awqaf}

The term maqsad (plural: maqasid) refers to "purpose, objective, principle, intent, goal, or end." 15 When referred to as the maqasid al-Shari'ah, the word denotes the purposes behind the rulings in the Shari'ah. There have been detailed discussions of this elsewhere, and thus this brief paper need not elaborate further. ${ }^{16}$ However, with relevance to the maqasid of zakah and awqaf, the objectives would fall under the specific category of the maqasid almu'amalat (objectives of financial transactions). Among the broad objectives which the Islamic law of financial transactions and contracts commonly upholds, Ibn 'Ashur (d. 1973) identified five such maqasid: circulation of wealth 
(rawaj or tadawul), transparency (wuduh), preservation (hifz), durability and sustainability (thubat), and equity ( $a d l) .{ }^{17}$ Other objectives include transfer of ownership (tamlik), civilisational construct ('imarah al-ard/'umran), and lawful acquisition of wealth $(k a s b){ }^{18}$

Similarly, the institutions of zakah and awqaf, which play vital roles in the development of Muslim communities, whether in terms of education, health, infrastructure, or economics, do have certain maqasid behind their enactment in the Shari'ah. Among the major maqasid which zakah and awqaf institutions ought to uphold are the following:

1. One of the main objectives behind enacting charities in the Qur'an, including zakah and awqaf, is the purification of the heart by curbing selfishness and material greed. This is evident from Surah al-Taubah (9:103), which commands the Prophet (pbuh) to take alms (sadaqat) from the believers' wealth to purify and sanctify them. Besides, Surah Aal-i-'Imran (3:92) demands the believers spend on the path of Allah from the most beloved of their properties, which directly crushes one's desires for materialistic greed and avarice. Previous passages have mentioned how the companions understood the objectives of awqaf and donated their best possessions for the sake of Allah. These are in concordance with enriching one's spiritual life by training one to get rid of excess material means.

2. Zakah and awqaf as wealth ( $\mathrm{mal}$ ) in general are both deemed to be transferred from the rich to the poor. This creates circulation of wealth through transfer of ownership - serving the general maqsad of rawaj. An inherent objective behind circulation is to prevent the rich from becoming richer and the poor from becoming poorer, thus creating a balanced and equitable economy. This is also reflected in the Qur'anic verse of Surah al-Hashr (59:7). This verse also urges the believers to take proactive measures in reducing the gaps between the haves and have-nots and alleviate poverty in society, thereby demonstrating the direct roles of zakah and awqaf in inclusive finance.

3. In a number of verses (51:19, and 70: 24-25), the Holy Qur'an mentions a distinct objective of zakah: that it is a 'right' of the poor and destitute. This stresses the Qur'anic emphasis on poverty alleviation through zakah. Zakah as an obligatory charity for the poor is undoubtedly an important tool for poverty eradication, which has been proven historically.

4. Another maqsad of zakah is that it confirms an individual as part of the greater Muslim community, as the verse 9:11 underlines. This also emphasises the significance of zakah as the most important financial 
pillar of Islam. As a matter of fact, zakah contributes to building the Islamic identity of an individual, and constitutes a fundamental element of communal harmony and cooperation among Muslims.

5. Awqaf generally consists of real assets which are to be developed and turned into a productive asset so that benefits can be reaped on a perpetual basis. This means that the economic activities under awqaf programs should be sustainable, efficient, economically viable and profitable lest the principle asset is consumed and renders no benefit. Thus it complements the maqsad of permanence and sustainability (thubat) in specific terms, and the maqsad of preservation of wealth (hifz al-mal) from a broader perspective.

6. Awqaf were originally meant for rendering undeveloped lands and assets to fruitful projects, thus fulfilling the maqsad of construction of civilisation (i'mar al-ard). Surah Hud (11:61) refers to isti'mar (civilisational construct) as a purpose behind the creation of human beings, thereby making humanity responsible for maintaining 'umran (civilisation). Awqaf projects, such as hospitals, educational institutions, inns and rest houses, public parks, public facility spaces, and the like, are clear examples of awqaf's contribution to the civilisational construct. Similarly, zakah has the potential to contribute to the development of 'umran by influx of wealth to the economy, as was the case during the reign of Umar ibn Abd al-Aziz (mentioned earlier).

7. The verse in Surah al-Taubah (9:103) commanding the Prophet (pbuh) to collect zakah implies that zakah should be collected by the government or another responsible authority. The institution of zakah thus requires transparency, good governance, legal documentation, and creation of employment opportunities for many to serve in the zakah collection process. Similarly, awqaf institutions should be brought under proper management to maximise their utility. These purposes come in as secondary objectives (maqasid tab'iyah) for the institutions of zakah and awqaf. Habib Ahmed suggests that the Muslim states and governments should strengthen their administration, legal and regulatory frameworks, and effective organizational structures in order to enhance the process of collection and distribution of zakah and awqaf for poverty alleviation purposes. ${ }^{19}$ Transparency, good governance, diligent administration and job creation are among the core tools for social inclusion. In fact, without these, social inclusion would remain impossible. These connect the immense potentials of zakah and awqaf with inclusive finance. 
It may be suggested that the maqasid identified above can be fulfilled by implementing projects based on zakah and awqaf. Having said so, the maqasid of the two institutions are not confined to that which has been discussed above. The rest of this article will explore and expand further maqasid for zakah and awqaf.

\section{Roles of Zakah and Awqaf in Inclusive Finance}

'Financial inclusion' used to refer to providing financial services and facilities to the low-income segments of society, at a very affordable cost. Currently, around $73 \%$ of poor people do not have any formal banking or financial services, due to complex banking requirements, the distance from their place of abode to the banking facilities, or the excessive costs of opening a simple banking account. ${ }^{20}$ In addition, more than 200 million formal small and medium sized enterprises (SMEs) in emerging markets lack access to finance. ${ }^{21}$ This hinders growth, productivity, employment, stability, and as such compromises peace, security and prosperity of the society at large. However, in the past decade, the term 'financial inclusion' has evolved into a four dimension framework, which includes: a) easy access to finance for all households and enterprises, b) sound institutions guided by prudential rules and regulations, c) financial and institutional sustainability, and d) competition between service providers to deliver alternative programmes to beneficiaries and customers. ${ }^{22}$

The office of the United Nations Secretary-General's Special Advocate for Inclusive Finance for Development (UNSGSA) in its mandate for inclusive finance, observes that financial inclusion aims to help people and communities meet their basic needs, such as safe housing and shelter, nutritious food, healthcare facilities, education and clean water facilities, and to promote financial institutions and businesses which provide them with these services. ${ }^{23}$ Most of these services are generally covered under any typical zakah or awqaf project. Zakah and awqaf institutions aim to contribute to the development of society in all possible forms. Historically, significant educational institutions, healthcare services, mosques and other places of worship, rest houses or inns, huge arable lands producing fruits and agricultural products for beneficiaries, and many other poverty alleviation projects and inclusive finance tools were successfully established and administered from the proceeds of zakah and awqaf. ${ }^{24}$ The Ottomans left behind a glorious example of awqaf for us. Waqf became a norm during Ottoman rule, so much so that even the non-Muslims endowed large amounts of property for the benefit of the entire society. To reflect its immense significance and the unparalleled central role it played in the Ottoman Empire, it would not be considered an exaggeration to say that a person would be born in a waqf house, sleep in a waqf cradle, eat and drink from waqf properties, read waqf 
books, go to a waqf school, receive salaries from a waqf institution, and, when they died, be placed in a waqf coffin and buried in a waqf cemetery. ${ }^{25}$ Such was the inclusive role which waqf played in society.

In our contemporary era too, and like the illustrious successes of the past, we find many inspiring results of zakah and awqaf-based programmes. For instance, the Selangor Zakah Council (Lembaga Zakat Selangor - LZS) in Malaysia, through its 'Zakat for Asnaf's Business' programme, has set convincing examples of eradicating poverty. Its beneficiaries were given capital for investment in their small and medium-sized businesses, with continuous assistance and support from relevant stakeholders and regular monitoring. Thus, the beneficiaries were soon able to start their own entrepreneurships, bidding farewell to poverty. ${ }^{26}$

Zakah and awqaf-based institutions may also replicate the ARI-AIM-Mydin Business Transformation model for a sustainable chain of business ventures. The Accounting Research Institute (ARI) of the Universiti Teknologi MARA (UiTM), Malaysia, together with Amanah Ikhtiar Malaysia (AIM) and Mydin Mohamad Holding Berhad initiated a poverty eradication model, whereby financing from AIM supported rural women in setting up a tailoring business. AIM also sponsored the building of a special workshop with ample sewing machines, tools, furniture, an office and an exhibition room for the baju kurung (local Malaysian ladies' dress) prepared by the beneficiaries. Mydin Mohamad Holding Berhad, a local supply chain hypermarket, supplied the raw materials to the beneficiaries and sold the produced baju kurung in their stores. Hence, Mydin played the important role of supplying raw materials and marketing the produced goods, completing the supply chain cycle. Since Mydin has its own reputation as an established hypermarket, marketing of the produced good is not a concern. As a retailer selling the produced goods, it has also guaranteed the sustainability of the entire model. ${ }^{27}$ The success of this model prompted its replication both in the state of Terengganu, Malaysia, under the joint collaboration of ARI, Mydin Holdings and Yayasan DiRaja Sultan Mizan (YDSM), and in three distinct Malaysian cities. ${ }^{28}$ The model is among the three Islamic economic transformation models initiated by ARI, which includes Islamic microfinance, Islamic social entrepreneurship and corporate waqf. No doubt it represents another success story of the waqf-based inclusive finance model.

An important factor differentiating inclusive finance from the institutions of zakah and awqaf is that the former is dependent on a financial system based primarily on interest (riba). By contrast, zakah and awqaf are totally interestfree, charitable institutions. The institutions of zakah and awqaf do not burden the client with any additional pressure to pay interest, but rather assist in coming out of that vicious process. 
Interest hinders economic growth and social development in various ways. Finance based on interest creates debt, and debt creates instability in the economy. It also results in inequity in the distribution of income and wealth, which causes inefficient allocation of resources. ${ }^{29}$ The frequently cited menace in the European debt crisis of "privatisation of profit and socialisation of loss" explains the enormous effects of debt on society and civilization. Debts, along with the interest and profits paid over the capital borrowed, causes inflation. National development declines due to less expenditure from the government. Similarly, there is a sharp decrease in national investment, since the wealth created is spent on huge unpaid debts. ${ }^{30}$ Increased cost of living due to economic inflation increases distress among general people, and restricts their productive contributions to economic and social development. The effects of debts are undoubtedly alarming. Hence, an inclusive finance agenda based on debt or interest will not be successful. Alternatively, philanthropic institutions like zakah and awqaf have more potential for successful poverty alleviation. Financial inclusion in the conventional sense could be successful only if interest is eliminated while the financial service is rendered to facilitate the non-bankable segment.

\section{Conclusions and Recommendations}

Despite the active presence of a large number of poverty alleviation institutions around the globe, a vast number of people still live below the poverty line, and many do not have access to healthcare, sanitation, safe drinking water and basic nutrition. These issues are worsening with the current political and economic turmoil. Research shows that the major reasons behind the slow pace of poverty alleviation include: the high interest rates applied to the credit taken from conventional microfinance institutions (MFIs), low human development, and, most notably a lack of balance between spiritual life and material life. ${ }^{31}$ Many MFIs have been unsuccessful in transferring wealth to beneficiaries; rather their clients remain trapped within the cycle of debt and loan repayment, effectively excluding them from financial services. ${ }^{32}$

Undoubtedly the bigger problem is the imposition of interest by conventional microfinance institutions and poverty alleviation programmes. Islamic microfinance institutions, however, may not impose interest. Nevertheless, the cost of profit can at times becomes burdensome for the client. Therefore, it is strongly argued here that the following policies should be considered for enhancing inclusive finance, especially by the Islamic financial tools of zakah and awqaf:

- Eradicate interest from poverty alleviation programmes. In fact, zakah and awqaf are two vital institutions which could play a decisive role in 
this process. Although financial inclusion may be successful at rendering financial services to the un-bankable, because it is interest based it is not likely to ultimately serve any fruitful purpose, which zakah and awqaf institutions ought to.

- Offering employment opportunities to target group and beneficiaries, rather than providing cash loans - be it interest free (qard hasan) or otherwise. Employment would lessen the burden of loan repayments, and encourage the target group to work and develop skills.

- Zakah and awqaf-based projects would be instrumental in transferring ownership of assets to the target groups. This would accelerate poverty alleviation, while fulfilling the maqasid of the two institutions.

\section{Notes}

* Tawfique al-Mubarak is a Research Fellow at IAIS Malaysia. He obtained his Bachelors degree from the International Islamic University Malaysia (IIUM) in 2007, and went on to complete a first M.A. in Islamic Banking, Finance and Management from the University of Gloucestershire in 2009, and a second M.A. in Islamic Studies (Contemporary Fiqh) from the Hamad bin Khalifa University in the State of Qatar in 2012. Email: tawfique@iais.org.my

1. A United Nations Capital Development Fund (UNCDF), "Inclusive Finance for Inclusive Growth", Available Online: http://www.uncdf.org/en/our-approach-0, Accessed on $20^{\text {th }}$ April, 2016.

2. M. N. Siddiqi, "The guarantee of a minimum level of living in an Islamic state," in Iqbal, Munawar (Ed.), Distributive Justice and Need Fulfilment in an Islamic Economy, Leicester: Islamic Foundation UK, 1988, 251; M. Umar Chapra, Islam and the economic challenge, Leicester and Herndon, Virginia: Islamic Foundation UK and International Institute of Islamic Thought, 1992, p. 209.

3. Surah al-Shams (91): 9; Al-A'la (87): 14

4. Surah an-Najm (53): 32

5. Yusuf Al-Qaradawi, Fiqh al-Zakah, translated by Monzer Kahf, Jeddah: King Abdul Aziz University, 2000, vol.1: xxxix.

6. A detailed discussion on the nisab of the different categories of items is provided in Yusuf Al-Qaradawi, Fiqh al-Zakah, translated by Monzer Kahf, Jeddah: King Abdul Aziz University, 2000, vols. 1 and 2.

7. Ahmed Bello Dogarawa, "Poverty Alleviation Through Zakah and Waqf Institutions: A Case for the Muslim Ummah in Ghana", paper presented at the First National Muslim Summit, Tamale, Ghana, $3^{\text {rd }}$ October 2010, p. 17.

8. Shinsuke Nagaoka, "Resuscitation of the Antique Economic System or Novel Sustainable System?: Revitalization of the Traditional Islamic Economic Institutions (Waqf and Zakat) in the Post-Modern Era," Kyoto Bulletin of Islamic Area Studies, 7 (March 2014), p. 3.

9. IDB and UN-DESA, Summary of "The Role of Islamic Finance in Sustainable 
Development Financing and the Opportunities in Creating New Partnerships in the Implementation of the Post-2015 Development Agenda," Jeddah: IDB Head Quarters, 2nd June, 2014; and IDB, "Waqf \& Zakat: Solidarity-Based Financing for Sustainable Development" presentation available online at 'UN Sustainable Development Knowledge Platform': https://sustainabledevelopment.un.org/ content/documents/10289Mahiridrissipresentation.pdf, $6^{\text {th }}$ June, 2014, Accessed on $17^{\text {th }}$ September, 2015.

10. Imtiyaz B. Ali, Waqf: A Sustainable Development Institution for Muslim Communities, Trinidad \& Tobago: Takaful T\&T Friendly Society, 2009, p. 7.

11. Ibn Kathir, Tafsir al-Qur'an al- 'Azim (Tafsir Ibn Kathir), n.p.: Dar Tayyibah, 1999, vol.2, pp. 73-4.

12. Ibn Qudamah, Al-Mughni fi Fiqh al-Imam Ahmad ibn Hanbal al-Shaybani, Beirut: Dar al-Fikr, 1405H., vol.6, p. 206.

13. See Habib Ahmed, Role of Zakah and Awqaf in Poverty Alleviation, Jeddah: IRTI, IDB, 2004, pp.72-3

14. The hadith appears in various wordings but always with the same message. An authentic (sahih) version appears in Imam Muslim ibn al-Hajjaj, Sahih Muslim, edited Fuad Abd. Al-Baqi, Beirut: Dar Ihya al-Turath al-Arabi, vol.3, 1255, hadith no: 1631. Another version of this hadith mentions 'an act which benefits people' instead of 'knowledge which benefits people,' see Abu Bakr ibn Khuzaimah, Sahih ibn Khuzaimah, edited Mustafa A'zami, Beirut: al-Maktab al-Islami, vol.4, 122, hadith no: 2494.

15. Jasser Auda, Maqasid al-Shariah as Philosophy of Islamic Law: A Systems Approach, London and Washington: IIIT, 2008, pp. 2-3.

16. For instance see Mohammad Hashim Kamali, Maqasid al-Shari'ah, Ijtihad and Civilizational Renewal, London and Washington: IIIT, and KL: International Institute of Advanced Islamic Studies (IAIS) Malaysia, 2012.

17. M. Tahir Ibn 'Ashur, Ibn Ashur's Treatise on the Higher Objectives \& Intents of Islamic Law, Mohamed El-Tahir El-Mesawi, (trans.), London and Washington: IIIT, 2006, p. 282.

18. See Abdullah bin-Bayyah, Maqasid al-Mu'amalat wa-Marasid al-Waqi'at, London: Al-Furqan Islamic Heritage Foundation, 2010, pp. 69-77.

19. Habib Ahmed, Role of Zakah and Awqaf in Poverty Alleviation.

20. 'Financial Inclusion: Overview', The World Bank, Available online: http:// www.worldbank.org/en/topic/financialinclusion/overview\#1, April 22, 2015, Accessed on $3^{\text {rd }}$ May, 2016.

21. The United Nations Secretary-General's Special Advocate for Inclusive Finance for Development (UNSGSA), 'The Imperative of Financial Inclusion,' available online: http://www.unsgsa.org/about/financial-inclusion, Accessed on $17^{\text {th }}$ September, 2015.

22. Asli Demirgüç-Kant, Thorsten Beck, and Patrick Honohan, Finance For All?: Policies and Pitfalls in Expanding Access, Washington DC: The World Bank, 2007.

23. The United Nations Secretary-General's Special Advocate for Inclusive Finance for Development (UNSGSA), 'The Imperative of Financial Inclusion,' available online: http://www.unsgsa.org/about/financial-inclusion, Accessed on $17^{\text {th }}$ September, 2015. 
24. For brief information on some of the major contributions of zakah and awqaf in Muslim history, see Ahmad Bello Dogarawa, 'Poverty Alleviation Through Zakah and Waqf Institutions: A Case for the Muslim Ummah in Ghana,' paper presented at the First National Muslim Summit organized by Al-Furqan Foundation, Tamale, Ghana, Held at Radach Memorial Centre, Lamashegu, Tamale, Ghana, $3^{\text {rd }}$ October, 2009, pp. 9-13.

25. Imtiyaz B. Ali, op cit, pp.12-3.

26. Nurul Husna Haron, Hazlina Hassan, Nur Syuhada Jasni, Rashidah Abdul Rahman, "Zakat for Asnaf's Business by Lembaga Zakat Selangor" Malaysian Accounting Review, Vol.9 (2), 2010, pp. 123-38.

27. See Tawfique Al-Mubarak, "Going 'Beyond Microfinance:' Enhancing Islamic Microfinance in Bangladesh", Islam and Civilisational Renewal, Vol.5 no.1, January 2014, pp.116-7.

28. For details on the structures and model, see: 'Economic Transformation Program in Terengganu', Accounting Research Institute (HICoE), available online: http:// accounting-research-institute.blogspot.my/2016/03/economic-transformationprogram-in.html, March 17, 2016, Accessed on $3^{\text {rd }}$ May, 2016.

29. M. Nejatullah Siddiqi, The Economics of Tawarruq: How its Mafasid Overwhelm the Masalih, available at: http://www.siddiqi.com/mns/Economics of Tawarruq.pdf, Accessed on $3^{\text {rd }}$ May, 2013.

30. For a detailed discussion on the effects of debt, see Abdul Karim Abdullah, "Debt and Economic Activity," Islam and Civilisational Renewal, vol. 4, no. 3, July 2013, 407-22.

31. A. H. M. Sadeq, M. Kabir Hassan, and Dewan A.H. Alamgir, Microfinance Services and Poverty alleviation in Bangladesh. A Comparative Analysis of Secular and Islamic NGOs, Paper Presented at the Fourth International Conference on Islamic Economics and Banking: Islamic Finance-Challenges and Opportunities in the Twenty-First Century, organised by International Association for Islamic Economics; IRTI-IDB, The Islamic Foundation UK and the Loughborough University, held on August 13-I5, 2000, at Loughborough University, UK.

32. Abu Umar Faruq and Tawfique Al-Mubarak, Principles and Practices of Islamic Microfinance for a Global Economy: A Case of Bangladesh, Germany: LAP, 2011.

\section{References:}

Al-Qur'an al-Karim

A. H. M. Sadeq, M. Kabir Hassan, and Dewan A.H. Alamgir, Microfinance Services and Poverty Alleviation in Bangladesh. A Comparative Analysis of Secular and Islamic NGOs, Paper Presented at the Fourth International Conference on Islamic Economics and Banking: Islamic Finance-Challenges and Opportunities in the Twenty-First Century, organized by International Association for Islamic Economics; IRTI-IDB, The Islamic Foundation UK and the Loughborough University, held on August 13-I5, 2000, at Loughborough University, UK. 
Abdul Karim Abdullah, "Debt and Economic Activity," Islam and Civilisational Renewal (ICR), vol. 4, no. 3, July 2013, pp. 407-22.

Abdullah bin-Bayyah, Maqasid al-Mu'amalat wa-Marasid al-Waqi'at, London: AlFurqan Islamic Heritage Foundation, 2010,

Abu Bakr ibn Khuzaimah, Sahih ibn Khuzaimah, edited Mustafa A'zami, Beirut: alMaktab al-Islami.

Abu Umar Faruq and Tawfique Al-Mubarak, Principles and Practices of Islamic Microfinance for a Global Economy: A Case of Bangladesh, Germany: LAP, 2011

Ahmad Bello Dogarawa, 'Poverty Alleviation Through Zakah and Waqf Institutions: A Case for the Muslim Ummah in Ghana,' paper presented at the First National Muslim Summit organized by Al-Furqan Foundation, Tamale, Ghana, Held at Radach Memorial Centre, Lamashegu, Tamale, Ghana, $3^{\text {rd }}$ October, 2009.

Asli Demirgüç-Kant, Thorsten Beck, and Patrick Honohan, Finance For All?: Policies and Pitfalls in Expanding Access, Washington DC: The World Bank, 2007

'Economic Transformation Program in Terengganu', Accounting Research Institute (ARI HICoE), available online: http://accounting-research-institute.blogspot. my/2016/03/economic-transformation-program-in.html, March, 2016.

'Financial Inclusion: Overview', The World Bank, Available online: http://www. worldbank.org/en/topic/financialinclusion/overview\#1, April 22, 2015

Habib Ahmed, Role of Zakah and Awqaf in Poverty Alleviation, Jeddah: IRTI, IDB, 2004.

Ibn Kathir, Tafsir al-Qur'an al- 'Azim (Tafsir Ibn Kathir), n.p.: Dar Tayyibah, 1999.

Ibn Qudamah, Al-Mughni fi Fiqh al-Imam Ahmad ibn Hanbal al-Shaybani, Beirut: Dar al-Fikr, 1405H.

Ibrahim ibn Musa (Abu Ishaq) al-Shatibi, Al-Muwafaqat fi Usul al-Shari'ah, edited by A. 'U. Mashhur Hasan, n.p.: Dar Ibn 'Affan, 1997.

IDB and UN-DESA, Summary of "The Role of Islamic Finance in Sustainable Development Financing and the Opportunities in Creating New Partnerships in the Implementation of the Post-2015 Development Agenda," Jeddah: IDB Head Quarters, $2^{\text {nd }}$ June, 2014; and IDB, "Waqf \& Zakat: Solidarity-Based Financing for Sustainable Development" presentation available online at "UN Sustainable Development Knowledge Platform': https://sustainabledevelopment.un.org/content/documents/10 289Mahiridrissipresentation.pdf, $6^{\text {th }}$ June, 2014.

Imran Ahsan Khan Nyazee, Outlines of Islamic Jurisprudence, e-book: Advanced Legal Studies Institute, n.d.

Imtiyaz B. Ali, Waqf: A Sustainable Development Institution for Muslim Communities, Trinidad \& Tobago: Takaful T\&T Friendly Society, 2009.

Jasser Auda, Maqasid al-Shariah as Philosophy of Islamic Law: A Systems Approach, London and Washington: IIIT, 2008. 
M. N. Siddiqi, "The guarantee of a minimum level of living in an Islamic state," in Iqbal, Munawar (Ed.), Distributive Justice and Need Fulfilment in an Islamic Economy, Leicester: Islamic Foundation UK, 1988.

M. N. Siddiqi, The Economics of Tawarruq: How its Mafasid Overwhelm the Masalih, available at: http://www.siddiqi.com/mns/Economics_of_Tawarruq.pdf, Accessed on $3^{\text {rd }}$ May, 2013.

M. Tahir Ibn 'Ashur, Ibn Ashur's Treatise on the Higher Objectives \& Intents of Islamic Law, Mohamed El-Tahir El-Mesawi, (trans.), London and Washington: IIIT, 2006, p. 282.

M. Umar Chapra, Islam and the economic challenge, Leicester and Herndon, Virginia: Islamic Foundation UK and International Institute of Islamic Thought, 1992.

Mohammad Hashim Kamali, Maqasid al-Shari'ah, Ijtihad and Civilizational Renewal, London and Washington: IIIT, and KL: International Institute of Advanced Islamic Studies (IAIS) Malaysia, 2012.

Muslim ibn al-Hajjaj, Sahih Muslim, edited Fuad Abd. Al-Baqi, Beirut: Dar Ihya al-Turath al-Arabi.

Nurul Husna Haron, Hazlina Hassan, Nur Syuhada Jasni, Rashidah Abdul Rahman, "Zakat for Asnaf's Business by Lembaga Zakat Selangor" Malaysian Accounting Review, Vol.9 (2), 2010.

Shinsuke Nagaoka, "Resuscitation of the Antique Economic System or Novel Sustainable System? Revitalization of the Traditional Islamic Economic Institutions (Waqf and Zakat) in the Post-Modern Era," Kyoto Bulletin of Islamic Area Studies, 7, March 2014.

Tawfique Al-Mubarak, “Going Beyond Microfinance:' Enhancing Islamic Microfinance Programs in Bangladesh,' Islam and Civilisational Renewal (ICR), vol.5 (1), January 2014, pp. 111-21.

The United Nations Secretary-General's Special Advocate for Inclusive Finance for Development (UNSGSA), 'The Imperative of Financial Inclusion,' available online: http://www.unsgsa.org/about/financial-inclusion.

United Nations Capital Development Fund (UNCDF), "Inclusive Finance for Inclusive Growth", Available Online: http://www.uncdf.org/en/our-approach-0.

Yusuf Al-Qaradawi, Fiqh al-Zakah, translated by Monzer Kahf, Jeddah: King Abdul Aziz University, 2000.

Yusuf Al-Qaradawi, Madkhal li-dirasatil-Shari'ah al-Islamiyyah, Beirut: Mu'assasat al-Risalah, 1993. 